Research Article

\title{
Effect of Different HTM Layers and Electrical Parameters on ZnO Nanorod-Based Lead-Free Perovskite Solar Cell for High-Efficiency Performance
}

\author{
Farhana Anwar, Rafee Mahbub, Sakin Sarwar Satter, and Saeed Mahmud Ullah \\ Department of Electrical and Electronic Engineering, University of Dhaka, Dhaka 1000, Bangladesh \\ Correspondence should be addressed to Farhana Anwar; farhanaanwar09@gmail.com
}

Received 22 May 2017; Revised 4 September 2017; Accepted 25 September 2017; Published 26 November 2017

Academic Editor: K. R. Justin Thomas

Copyright ( 2017 Farhana Anwar et al. This is an open access article distributed under the Creative Commons Attribution License, which permits unrestricted use, distribution, and reproduction in any medium, provided the original work is properly cited.

\begin{abstract}
Simulation has been done using SCAPS-1D to examine the efficiency of $\mathrm{CH}_{3} \mathrm{NH}_{3} \mathrm{SnI}_{3}$-based solar cells including various $\mathrm{HTM}$ layers such as spiro-OMeTAD, $\mathrm{Cu}_{2} \mathrm{O}$, and $\mathrm{CuSCN}$. $\mathrm{ZnO}$ nanorod array has been considered as an ETM layer. Device parameters such as thickness of the $\mathrm{CH}_{3} \mathrm{NH}_{3} \mathrm{SnI}_{3}$ layer, defect density of interfaces, density of states, and metal work function were studied. For optimum parameters of all three structures, efficiency of $20.21 \%, 20.23 \%$, and $18.34 \%$ has been achieved for spiro-OMeTAD, $\mathrm{Cu}_{2} \mathrm{O}$, and $\mathrm{CuSCN}$, respectively. From the simulations, an alternative lead-free perovskite solar cell is introduced with the $\mathrm{CH}_{3} \mathrm{NH}_{3} \mathrm{SnI}_{3}$ absorber layer, $\mathrm{ZnO}$ nanorod ETM layer, and $\mathrm{Cu}_{2} \mathrm{O}$ HTM layer.
\end{abstract}

\section{Introduction}

In recent years, organometal halide perovskite solar cells (PSCs) have attracted significant interest of research community due to their optoelectronic behavior, high power conversion efficiency (PCE), and low manufacturing cost. Generally, organolead halide perovskite materials are used for producing perovskite solar cells. The PCE of $\mathrm{CH}_{3} \mathrm{NH}_{3} \mathrm{PbX}$ PSC has reached to approximately $22 \%$ in 2016 [1]. However, such kind of materials lacks long-term stability. Moreover, they are toxic and can bring health and ecological hazards as they contain lead $(\mathrm{Pb})$ [2]. Also, typical perovskite solar cells incorporate $\mathrm{TiO}_{2}$ as the ETM layer which can cause disturbed charge transport of perovskite solar cells [3]. In some fabrication techniques, the involvement of $\mathrm{TiO}_{2}$ increases the processing cost as it requires high temperature for deposition. These are the major limitations of the conventional perovskite solar cell structures which impedes the feasibility of their commercial production.

The toxicity of typical perovskite solar cells can be avoided by using $\mathrm{CH}_{3} \mathrm{NH}_{3} \mathrm{SnI}_{3}$, which has a direct bandgap of the value $1.30 \mathrm{eV}$, as an absorber layer. It has the most appropriate optical properties and the light-absorption range among all the $\mathrm{CH}_{3} \mathrm{NH}_{3} \mathrm{BX}_{3}(\mathrm{~B}=\mathrm{Sn}, \mathrm{Pb} ; \mathrm{X}=\mathrm{Cl}, \mathrm{Br}, \mathrm{I})$ compounds for optoelectrical applications [1]. Besides, recent studies have revealed that $\mathrm{ZnO}$ can be used as a proper substitute of $\mathrm{TiO}_{2}$ as the ETM layer without affecting the performance of PSCs significantly $[3,4]$. It has a direct bandgap of $3.37 \mathrm{eV}$. Such wide bandgap leads to high electron transport mobility. The efficiency of such a solar cell can be further enhanced when the nanostructured ETM layer is used. Unlike pure $\mathrm{ZnO}$, Au-/Al-doped $\mathrm{ZnO}$ nanorods (nr) has large conduction band, which leads to fast electron mobility and high electron density [5]. By optimizing the length and diameter of $\mathrm{ZnO}$ nanorods, the photovoltaic performance of the solar cell can be modified. Moreover, using $\mathrm{ZnO}$ nanorods instead of $\mathrm{TiO}_{2}$ as an ETM layer, the processing cost of PCSs can be reduced.

A model of a lead-free perovskite solar cell involving $\mathrm{CH}_{3} \mathrm{NH}_{3} \mathrm{SnI}_{3}$ is proposed. Device simulations using SCAPS1D have been done for Glass/FTO/ZnO nr/ $\mathrm{CH}_{3} \mathrm{NH}_{3} \mathrm{SnI}_{3} /$ $\mathrm{HTM} / \mathrm{Au}$ structure. For an HTM layer, both organic and inorganic materials were used to observe their influence on efficiency. We have considered spiro-OMeTAD, $\mathrm{Cu}_{2} \mathrm{O}$, and $\mathrm{CuSCN}$ as the HTM layer. From $I-V$ characteristics of all three structures, it was evident that the highest efficiency can be 


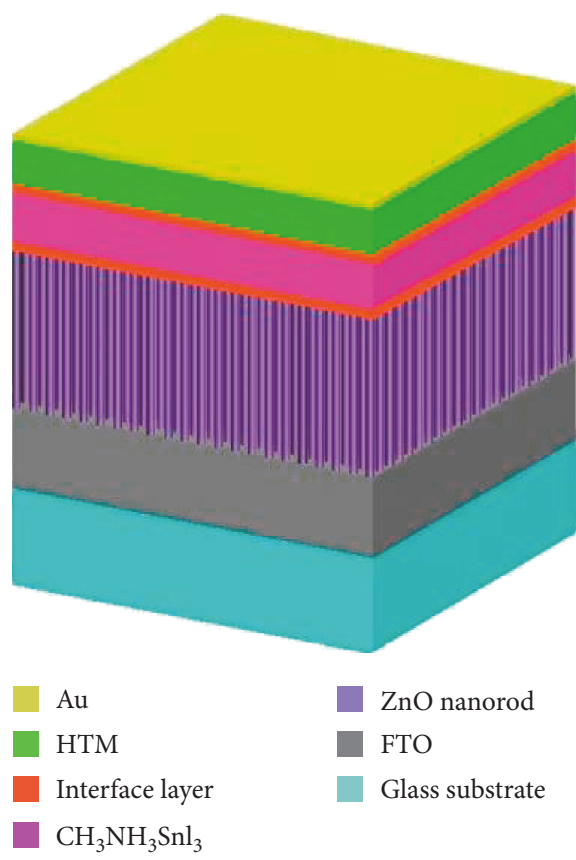

FIgURE 1: Device structure of $\mathrm{Pb}$-free perovskite solar cell.

achieved when $\mathrm{Cu}_{2} \mathrm{O}$ is considered as the HTM layer. To relate the performance of our proposed structures with previously examined $\mathrm{Pb}$-based perovskite solar cells, we have compared the efficiency for our Glass/FTO/ZnO $\mathrm{nr} / \mathrm{CH}_{3} \mathrm{NH}_{3} \mathrm{SnI}_{3} / \mathrm{Cu}_{2} \mathrm{O} / \mathrm{Au}$ structure with Glass/FTO/ZnO $\mathrm{nr} / \mathrm{CH}_{3} \mathrm{NH}_{3} \mathrm{PbI}_{3} / \mathrm{Cu}_{2} \mathrm{O} / \mathrm{Au}$ structure using the optimum values of their electrical parameters. From the obtained results of efficiency, it can be said that we can get similar efficiency for both structures. This indicates that the proposed lead-free PSC structure is feasible for the production of high-efficiency lead-free perovskite solar cells.

\section{Device Structure and Simulation}

We have considered methylammonium tin triiodide $\left(\mathrm{CH}_{3} \mathrm{NH}_{3} \mathrm{SnI}_{3}\right)$ as absorber layer and $\mathrm{Cu}_{2} \mathrm{O}$ /spiro-OMeTAD/ CuSCN as hole transport material (HTM) along with $\mathrm{ZnO}$ nanorod as electron transport material (ETM). It is a solid-state planar heterojunction p-i-n solar cell with low p-type-doped $\mathrm{CH}_{3} \mathrm{NH}_{3} \mathrm{PbI}_{3}$ [6] sandwiched between the n-type ETM and p-type HTM layer. Numerical simulation is performed using SCAPS-1D simulation software to analyze the effect of different electrical parameters on the efficiency of $\mathrm{ZnO}(\mathrm{nr}) / \mathrm{CH}_{3} \mathrm{NH}_{3} \mathrm{SnI}_{3} / \mathrm{Cu}_{2} \mathrm{O}, \mathrm{ZnO}(\mathrm{nr}) /$ $\mathrm{CH}_{3} \mathrm{NH}_{3} \mathrm{SnI}_{3} / \mathrm{CuSCN}$, and $\mathrm{ZnO}(\mathrm{nr}) / \mathrm{CH}_{3} \mathrm{NH}_{3} \mathrm{SnI}_{3}$ /spiroOMeTAD heterojunction-based perovskite solar cell structures. Figure 1 shows the device structure for the simulation, and Figure 2 shows the band alignment of $\mathrm{ZnO}$ nr-based lead-free PSC along with typical perovskite materials used in conventional PSCs.

SCAPS-1D is a one-dimensional solar cell simulation program based on three coupled differential equations, namely, Poisson's (1) and continuity equations for holes (2) and electrons (3) as follows:

$$
\begin{array}{r}
\frac{d}{d x}\left(-\varepsilon(x) \frac{d \psi}{d x}\right)=q\left[p(x)-n(x)+N_{\mathrm{d}}^{+}(x)\right. \\
\left.-N_{\mathrm{a}}^{-}(x)+p_{\mathrm{t}}(x)-n_{\mathrm{t}}(x)\right], \\
\frac{d p_{\mathrm{n}}}{d t}=G_{\mathrm{p}}-\frac{p_{n}-p_{\mathrm{n} 0}}{\tau_{\mathrm{p}}}-p_{\mathrm{n}} \mu_{\mathrm{p}} \frac{d \xi}{d x} \\
-\mu_{\mathrm{p}} \xi \frac{d p_{\mathrm{n}}}{d x}+D_{\mathrm{p}} \frac{d^{2} p_{\mathrm{n}}}{d x^{2}} \\
\frac{d n_{\mathrm{p}}}{d t}=G_{\mathrm{n}}-\frac{n_{p}-n_{\mathrm{p} 0}}{\tau_{\mathrm{n}}}+n_{\mathrm{p}} \mu_{\mathrm{n}} \frac{d \xi}{d x} \\
+\mu_{\mathrm{n}} \xi \frac{d n_{\mathrm{p}}}{d x}+D_{\mathrm{n}} \frac{d^{2} n_{\mathrm{p}}}{d x^{2}} .
\end{array}
$$

Here, $D$ is diffusion coefficient, $\psi$ is electrostatic potential, $q$ is electron charge, $G$ is generation rate, $\xi$ is permittivity, and $n, p, n_{\mathrm{t}}$, and $p_{\mathrm{t}}$ are free holes, free electrons, trapped holes, and trapped electrons, respectively. $N_{\mathrm{a}}^{-}$refers to ionized acceptor-like doping concentration, and $\mathrm{N}_{\mathrm{d}}{ }^{+}$stands for ionized donor-like doping concentration [7].

In the device simulation, $\mathrm{HTM} / \mathrm{CH}_{3} \mathrm{NH}_{3} \mathrm{SnI}_{3}$ and $\mathrm{CH}_{3} \mathrm{NH}_{3} \mathrm{SnI}_{3} / \mathrm{ETM}$ interface defect layer (IDL) are also considered to take into account the interface recombination due to interface defect density. Thermal velocity of electron and hole is $1 \times 10^{7} \mathrm{~cm} / \mathrm{s}$. All the simulations are done under an illumination of $1000 \mathrm{~W} / \mathrm{m}^{2}$, temperature of $25^{\circ} \mathrm{C}$, and an air mass of $1.5 \mathrm{G}$.

The values of device and material parameters used in SCAPS-1D for simulation that are adopted from theories and literatures $[1,2,8,9]$ are summarized in Tables 1,2 , and 3. The absorption coefficient for both $\mathrm{CH}_{3} \mathrm{NH}_{3} \mathrm{PbI}_{3}$ and $\mathrm{CH}_{3} \mathrm{NH}_{3} \mathrm{SnI}_{3}$ is calculated according to Umari et al. [2].

Using the optimum values of different electrical parameters found through simulation, we have simulated the device performance parameters such as short-circuit current density $J_{\mathrm{sc}}$, open-circuit voltage $V_{\mathrm{oc}}$, fill factor $\mathrm{FF}$, and power conversion efficiency PCE for different HTM-based perovskite solar cell and the final result is shown in Table 4.

\section{Effect of Thickness of the $\mathrm{CH}_{3} \mathrm{NH}_{3} \mathrm{SnI}_{3}$ Layer}

The efficiency of a perovskite solar cell depends largely on the response of solar spectrum which is influenced by the thickness of the absorber layer. Thickness of absorber layer is one of the major parameters and plays a vital role on the overall performance of the solar cell. Thickness of $\mathrm{CH}_{3} \mathrm{NH}_{3} \mathrm{SnI}_{3}$ has been varied from $300 \mathrm{~nm}$ to $1000 \mathrm{~nm}$ with the $\mathrm{Cu}_{2} \mathrm{O}$ /spiro-OMeTAD/CuSCN HTM layer and $\mathrm{ZnO} \mathrm{nr}$ as the ETM layer. The result is shown in Figure 3, and the thickness versus $V_{\text {oc }}$ curve is also shown in Figure 4. It is found that as the thickness of $\mathrm{CH}_{3} \mathrm{NH}_{3} \mathrm{SnI}_{3}$ is increased, the efficiency of the solar cell increases up to a certain value which is considered as optimum thickness for the solar cell. With increasing thickness, the short circuit current $\left(J_{\mathrm{sc}}\right)$ increases because a thicker absorber layer will absorb more 


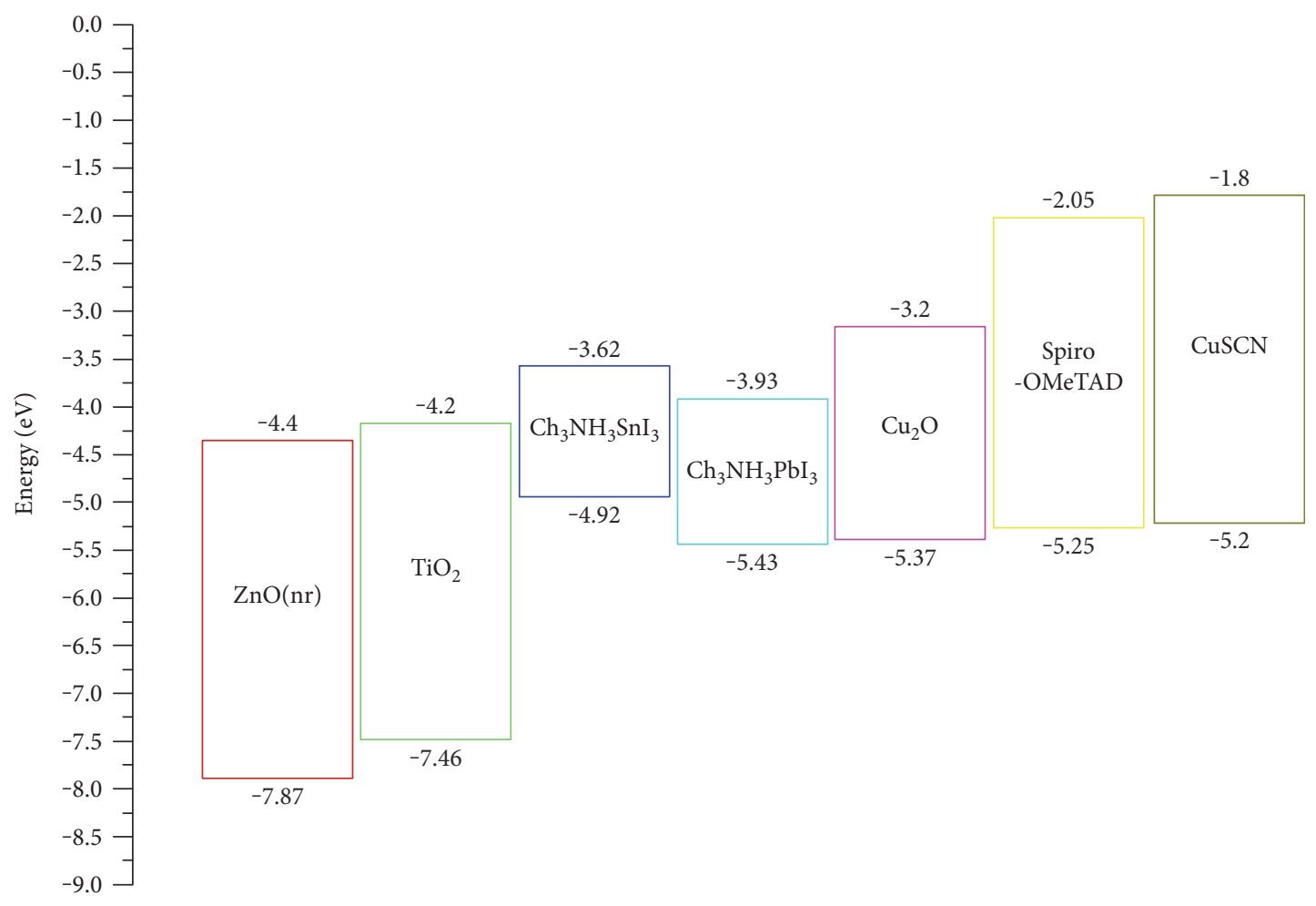

FIGURE 2: Energy band alignment.

TABLE 1: Parameters used for simulation of perovskite solar cell structures using SCAPS-1D.

\begin{tabular}{|c|c|c|c|c|c|c|}
\hline Parameters & $\mathrm{ZnO} \mathrm{nr}$ & $\mathrm{CH}_{3} \mathrm{NH}_{3} \mathrm{SnI}_{3}$ & $\mathrm{CH}_{3} \mathrm{NH}_{3} \mathrm{PbI}_{3}$ & $\mathrm{Cu}_{2} \mathrm{O}$ & Spiro-OMeTAD & $\mathrm{CuSCN}$ \\
\hline Thickness (nm) & $500[10]$ & 450 (variable) & 450 & 350 & 350 & 350 \\
\hline Bandgap (eV) & $3.47[10]$ & 1.30 & 1.50 & 2.17 & 3.2 & 3.4 \\
\hline Electron affinity $(\mathrm{eV})$ & $4.3[11]$ & 4.20 & 3.9 & 3.2 & 2.1 & 2.1 \\
\hline Dielectric permittivity (relative) & $9[12]$ & 10 & 10 & 7.1 & 3 & 10 \\
\hline $\mathrm{CB}$ effective density of states $\left(1 / \mathrm{cm}^{3}\right)$ & $2 E+18$ & $1.0 E+18$ & $2.25 E+18$ & $2.50 E+18$ & $2.5 E+18$ & $2.5 E+18$ \\
\hline VB effective density of states $\left(1 / \mathrm{cm}^{3}\right)$ & $1.8 E+20$ & $1.0 E+18$ & $1.0 E+18$ & $1.80 E+19$ & $1.8 E+19$ & $1.8 E+19$ \\
\hline Electron thermal velocity $(\mathrm{cm} / \mathrm{s})$ & $1 E+7$ & $1 E+7$ & $1.0 E+7$ & $1 E+7$ & $1.0 E+7$ & $1 E+7$ \\
\hline Hole thermal velocity $(\mathrm{cm} / \mathrm{s})$ & $1 E+7$ & $1 E+7$ & $1.0 E+7$ & $1 E+7$ & $1.0 E+7$ & $1 E+7$ \\
\hline Electron mobility $\left(\mathrm{cm}^{2} / \mathrm{Vs}\right)$ & $1.0 E+2$ & $1.6 E+0$ & $2.20 E+0$ & $2.0 E+2$ & $2.0 E-4$ & $2.0 E-4$ \\
\hline Hole mobility $\left(\mathrm{cm}^{2} / \mathrm{Vs}\right)$ & $2.5 E+1$ & $1.6 E+0$ & $2.20 E+0$ & $8.0 E+2$ & $2.0 E-4$ & $100 E-2$ \\
\hline Shallow uniform acceptor density, $N_{\mathrm{A}}\left(1 / \mathrm{cm}^{3}\right)$ & 0 & $3.2 E+15$ & $1.0 E+18$ & $9.0 E+21$ & $1.0 E+20$ & $1 E+18$ \\
\hline Shallow uniform donor density $N_{D}\left(1 / \mathrm{cm}^{3}\right)$ & $1 E+19$ & 0 & 0 & 0 & 0 & 0 \\
\hline Defect type & - & Neutral & Neutral & Neutral & Neutral & Neutral \\
\hline Capture cross section electrons $\left(\mathrm{cm}^{2}\right)$ & - & $1 E-16$ & $1 E-13$ & $1 E-15$ & $1 E-15$ & $1 E-15$ \\
\hline Capture cross section holes $\left(\mathrm{cm}^{2}\right)$ & - & $1 E-14$ & $1 E-13$ & $1 E-15$ & $1 E-15$ & $1 E-15$ \\
\hline Energetic distribution & - & Single & Single & Single & Single & Single \\
\hline Reference for defect energy level $E_{\mathrm{t}}$ & - & Above $E_{\mathrm{v}}$ & Above $E_{\mathrm{v}}$ & Above $E_{\mathrm{v}}$ & Above $E_{\mathrm{v}}$ & Above $E_{\mathrm{v}}$ \\
\hline Energy level with respect to reference $(\mathrm{eV})$ & - & 0.7 & 0.7 & 0.10 & 0.10 & 0.10 \\
\hline$N_{\mathrm{t}}$ total $\left(1 / \mathrm{cm}^{3}\right)$ uniform & - & $4.5 E+16$ & $1 E+12$ & $1 E+14$ & $1.00 E+14$ & $1 E+14$ \\
\hline
\end{tabular}

photons, which in turn will create more electron-hole pair. But with a thicker absorber layer, the chances of recombination also increase as the charges have to travel a longer distance for diffusion. Therefore, after a certain point, the efficiency decreases with the increasing thickness. This result is similar to the experimental result found by Correa-Baena 
TABLE 2: Parameters of interface layer.

\begin{tabular}{lcc}
\hline Interface layer & HTM/perovskite layer & Perovskite layer/ETM \\
\hline Defect type & Neutral & Neutral \\
Capture cross section electrons $\left(\mathrm{cm}^{2}\right)$ & $1.00 E-18$ & $1.00 E-15$ \\
Capture cross section holes $\left(\mathrm{cm}^{2}\right)$ & $1.00 E-16$ & $1.00 E-15$ \\
Energetic distribution & Single & Single \\
Reference for defect energy level $E_{\mathrm{t}}$ & Above the highest $E_{\mathrm{v}}$ & Above the highest $E_{\mathrm{v}}$ \\
Energy with respect to reference $(\mathrm{eV})$ & 0.050 & 0.600 \\
Total density (integrated over all energies) $\left(1 / \mathrm{cm}^{2}\right)$ & $1.00 E+12$ & $1.00 E+11$ \\
\hline
\end{tabular}

TABLE 3: Parameters for back and front contact.

\begin{tabular}{lcc}
\hline Parameters & Back contact & Front contact \\
\hline Surface recombination velocity of electrons $(\mathrm{cm} / \mathrm{s})$ & $1.000 E+5$ & $1.000 E+5$ \\
Surface recombination velocity of holes $(\mathrm{cm} / \mathrm{s})$ & $1.000 E+7$ & $1.000 E+7$ \\
Metal work function $(\mathrm{eV})$ & 5.1 & 4.3 \\
Majority carrier barrier height relative to $E_{\mathrm{f}}(\mathrm{eV})$ & 0.40 & 0.22 \\
Majority carrier barrier height relative to $E_{\mathrm{v}}(\mathrm{eV})$ & 0.3251 & -0.0776 \\
\hline
\end{tabular}

TABLE 4: Effect of different back contact.

\begin{tabular}{lccccc}
\hline Back contact material & $\mathrm{Ag}$ & $\mathrm{Fe}$ & $\mathrm{Cu}$ & $\mathrm{Au}$ & $\mathrm{Ni}$ \\
\hline Metal work function, $\Phi_{\mathrm{m}}(\mathrm{eV})$ & 4.74 & 4.81 & 5.00 & 5.10 & 5.50 \\
Efficiency $(\%)$ for $\mathrm{Cu}_{2} \mathrm{O}$ & 16.3 & 17.8 & 18.7 & 18.60 & 18.69 \\
Efficiency (\%) for CuSCN & 13.1 & 13.3 & 13.45 & 15.75 & 17.68 \\
Efficiency (\%) for spiro-OMeTAD & 13.9 & 14.7 & 17.7 & 17.80 & 17.72 \\
\hline
\end{tabular}

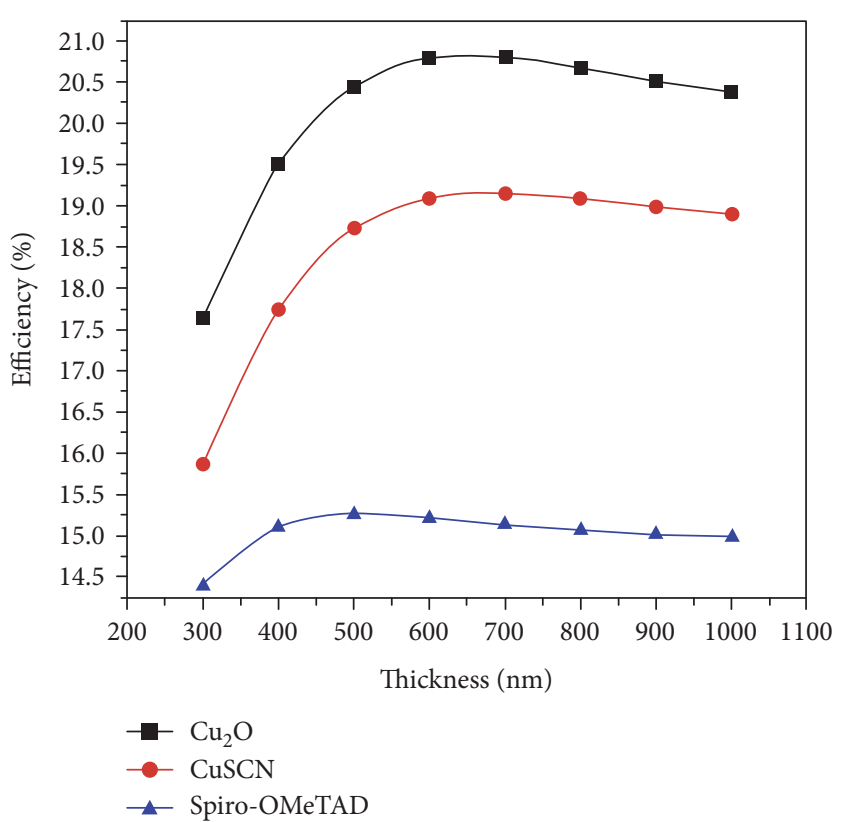

Figure 3: Thickness of the perovskite layer versus efficiency. et al. [13]. With the increasing thickness, the recombination expedites. Thus, $V_{\text {oc }}$ declines which in turn decreases the efficiency. Here, the $V_{\text {oc }}$ can be expressed as

$$
V_{\mathrm{oc}}=\left(\frac{A k T}{q}\right) \ln \left(\frac{I_{\mathrm{L}}}{I_{0}}+1\right),
$$

where $A$ is diode ideality factor, $I_{0}$ is dark saturation current, $I_{\mathrm{L}}$ is light-generated current, and $k T / q$ is thermal voltage. A thinner absorber layer causes less electron-hole recombination, which keeps the value of $I_{0}$ low. For this reason, the $V_{\text {oc }}$ remains high up to a certain absorber thickness. After that, with increasing absorber thickness, the value of $I_{0}$ increases and causes the value of $V_{\text {oc }}$ to decrease. Moreover, the fill factor decreases with the increasing thickness which leads to more internal power consumption [14].

The thickness of the absorber layer has to be selected in such a way, so that the diffusion length of the excess charge carrier is larger than the thickness. Since the perovskite material has a direct bandgap of $1.3 \mathrm{eV}$ and, also a high absorption coefficient $\sim 10^{5}$ [15], a thin absorber layer can produce high power conversion efficiency (PCE). It is found from the simulation that a thickness of $600 \mathrm{~nm}-700 \mathrm{~nm}$ would be sufficient enough for almost complete absorption of $\mathrm{AM} 1.5 \mathrm{G}$ radiation. A $650 \mathrm{~nm}$ thick absorber layer is 


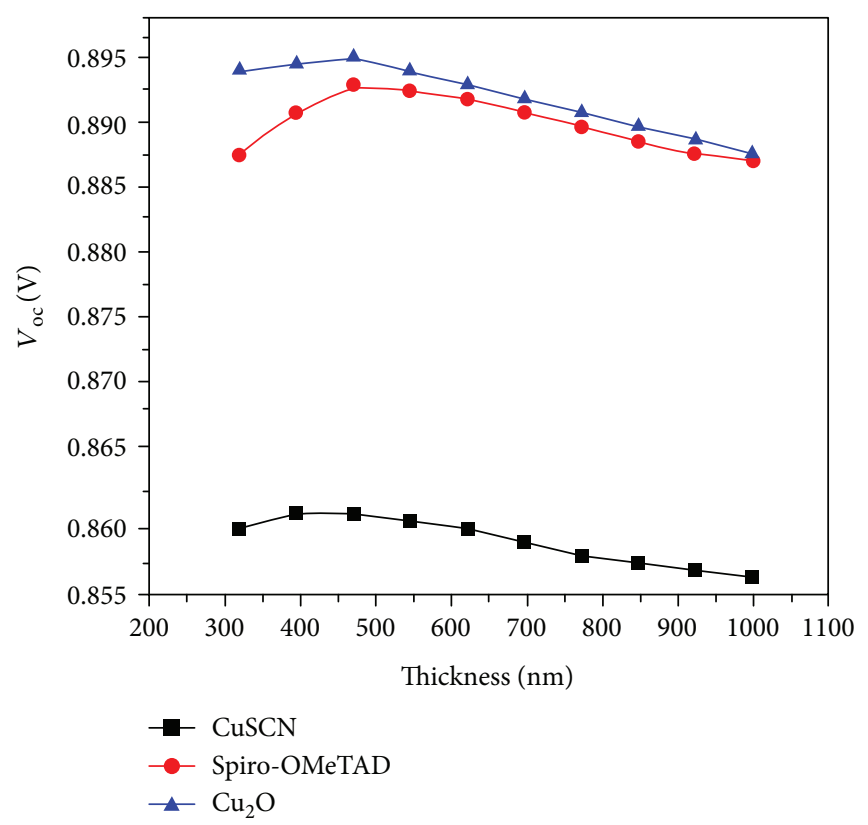

FIGURE 4: Thickness of the perovskite layer versus open circuit voltage.

optimum to get high PCE for perovskite solar cell as seen in Figure 3.

\section{Effects of the Defect State of the Interface Defect Layer $1\left(\right.$ ETM/ $\left.\mathrm{CH}_{3} \mathrm{NH}_{3} \mathrm{SnI}_{3}\right)$ and Interface Defect Layer $2\left(\mathrm{CH}_{3} \mathrm{NH}_{3} \mathrm{SnI}_{3} / \mathrm{HTM}\right)$}

Two defect layers have been considered for the simulations of the proposed $\mathrm{Pb}$-free perovskite solar cell structures. The $\mathrm{HTM} / \mathrm{CH}_{3} \mathrm{NH}_{3} \mathrm{SnI}_{3}$ layer and the $\mathrm{CH}_{3} \mathrm{NH}_{3} \mathrm{SnI}_{3} /$ ETM layer has been represented by IDL 1 and IDL 2, respectively. Numerical simulation has been performed on the defect density at both interfaces from $1 \times 10^{10} \mathrm{~cm}^{-3}$ to $1 \times 10^{16} \mathrm{~cm}^{-3}$. Figures 5 and 6 show the effect of interface defect density versus efficiency curves for different perovskite solar cell for both interface layers. From the graphs, it can be deduced that negligible effect on efficiency is observed till the defect density is below $1 \times 10^{12} \mathrm{~cm}^{-3}$. When the defect density exceeds $1 \times 10^{12} \mathrm{~cm}^{-3}$, decrease in efficiency is observed. With increasing defect density, the recombination rate also increases which in turn decreases the efficiency. So, it can be realized from the simulated results that interface defect density of $1 \times 10^{12} \mathrm{~cm}^{-3}$ is optimum for device simulation.

\section{Effect of Density of State (DOS) on the Absorber Layer}

To discern the effect of DOS of the p-type $\mathrm{CH}_{3} \mathrm{NH}_{3} \mathrm{SnI}_{3}$ on the efficiency of $\mathrm{Pb}$-free $\mathrm{ZnO}$ nanorod-based PSCs with different HTM layers, we have varied the density of state $\left(N_{\mathrm{v}}\right)$ from $1 \times 10^{17} \mathrm{~cm}^{-3}$ to $1 \times 10^{19} \mathrm{~cm}^{-3}$ and Figure 7 shows the graph of valance band effective density of state versus efficiency. From the graph, it can be said that the efficiency decreases with the increase of $N_{\mathrm{v}}$ of the p-type

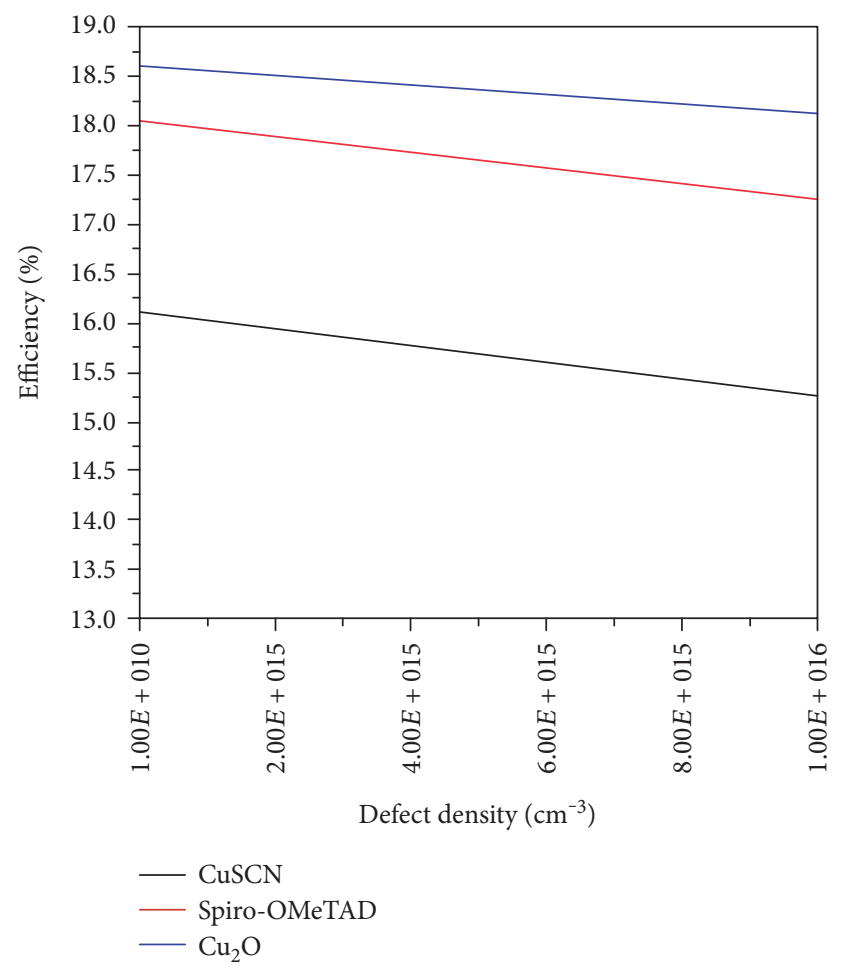

FIgure 5: Defect density of the ETM/ $\mathrm{CH}_{3} \mathrm{NH}_{3} \mathrm{SnI}_{3}$ layer versus efficiency.

absorber layer. As the number of holes increases at the absorber layer, their possibility of taking part in reverse saturation current also increases. Consequently, the open circuit voltage declines which leads to low electric conversion efficiency. 


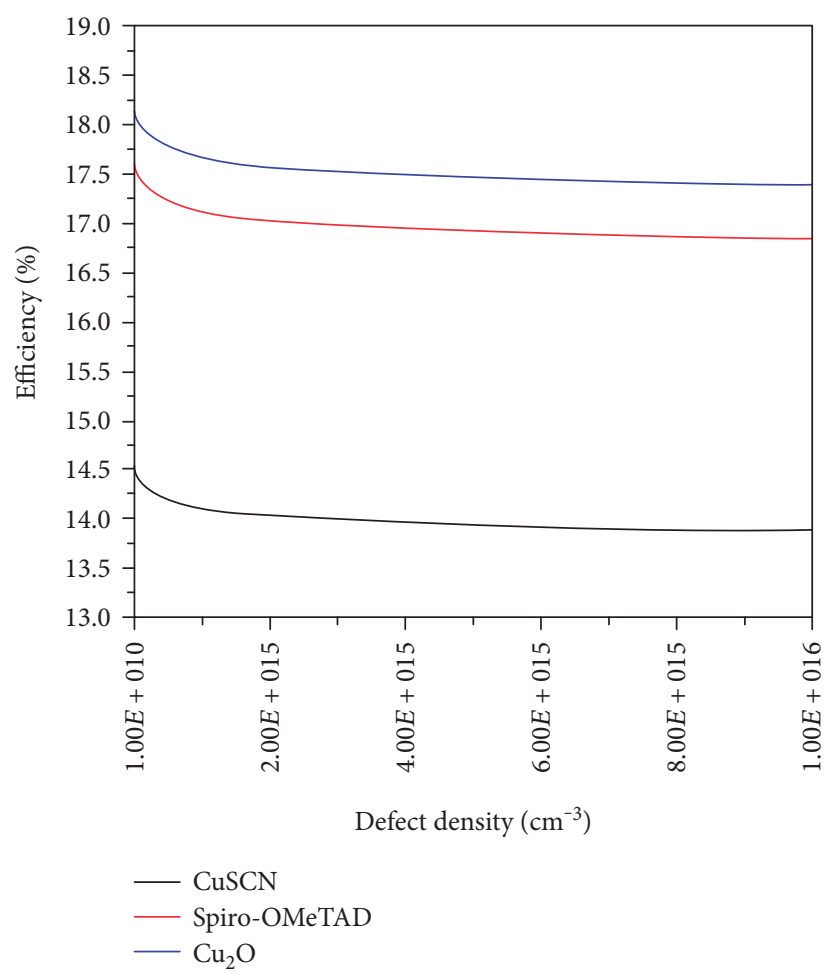

Figure 6: Defect density of the $\mathrm{CH}_{3} \mathrm{NH}_{3} \mathrm{SnI}_{3} / \mathrm{HTM}$ layer versus efficiency.

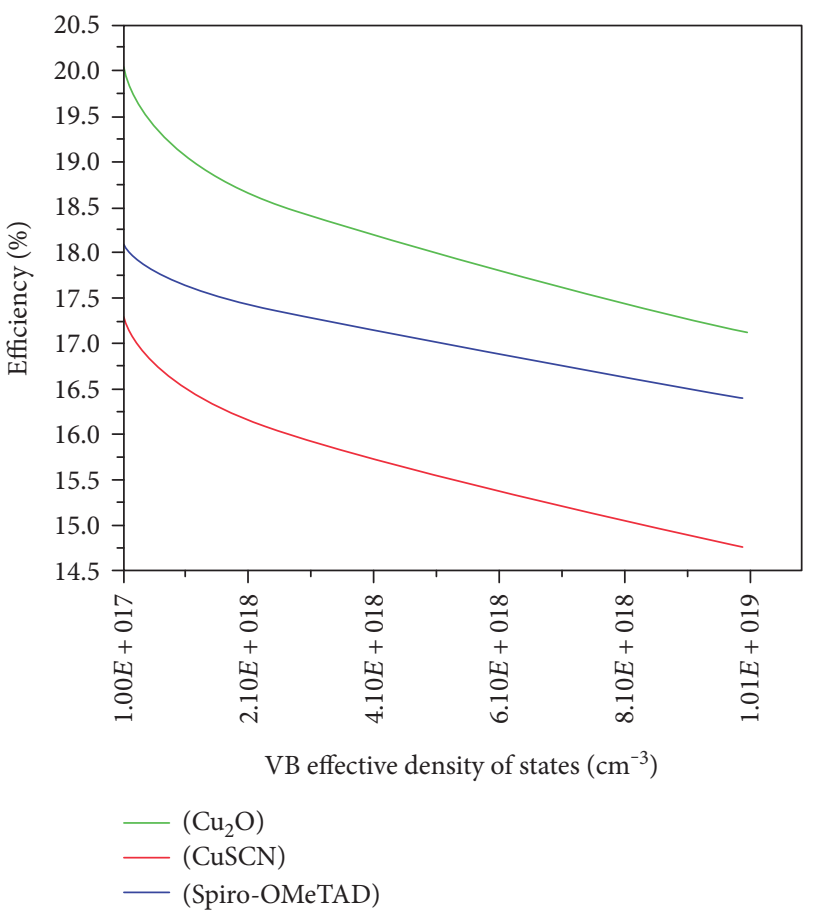

Figure 7: Valance band effective density of state versus efficiency.

\section{Effect of Different Back Contacts}

Simulations have been done using silver $(\mathrm{Ag})$, iron $(\mathrm{Fe})$, copper $(\mathrm{Cu})$ graphite alloy, gold $(\mathrm{Au})$, nickel $(\mathrm{Ni})$, and platinum $(\mathrm{Pt})$ as prospective back contact for perovskite solar cell.

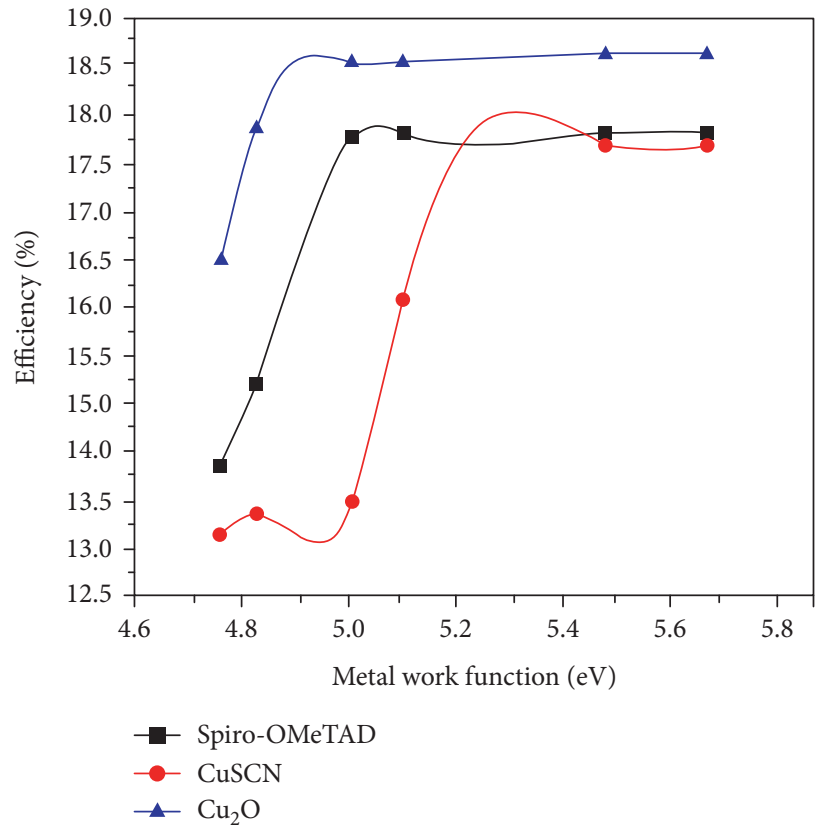

FIgURE 8: Metal work function versus efficiency.

Figure 8 illustrates the result of efficiency for different back contact. The performance of the simulated solar cells increases with increasing the work function but after a certain value, it saturates. With increasing metal work function, the majority carrier barrier height (relative to $E_{\mathrm{f}}$ ) decreases due to band bending at the metal-semiconductor interface, making the contact more ohmic [16]. As the work function of the metal increases, the $V_{\text {oc }}$ gets increased. Hence, the efficiency of perovskite solar cell also rises. It is energetically unfavorable for holes to travel towards the electrode because the electric field close to HTM/back contact becomes negative [17]. For this reason, it can be anticipated that lower work function is responsible for lower efficiency. The simulation results show that $\mathrm{Au}$ is one of the potential back contact material which can develop the performance of PSCs. The simulated results are similar to the results found by Behrouznejad et al. [17]. Additionally, the poor reflectivity in the visible region makes it appropriate for back contact material. Generally, an Au film of $50 \mathrm{~nm}$ is used as back contact in PSCs [18]. Table 4 shows the effect of various metal back contact on different candidates of the HTM layer.

\section{Numerical Analysis for Various HTM Candidates}

In this work, we have used spiro-OMeTAD, $\mathrm{Cu}_{2} \mathrm{O}$, and CuSCN as the HTM layer for the simulation of PSCs. All the HTM materials used in this work have been inspected in numerous publications as the HTM layer along with planar $\mathrm{TiO}_{2}$ and $\mathrm{ZnO}$ nanorod as the ETM layer of $\mathrm{CH}_{3} \mathrm{NH}_{3} \mathrm{PbI}_{3}$-based PSCs. However, this work focuses on to promote a lead-free perovskite solar cell structure with $\mathrm{ZnO}$ nanorod as the ETM layer. Along with the $I-V$ 

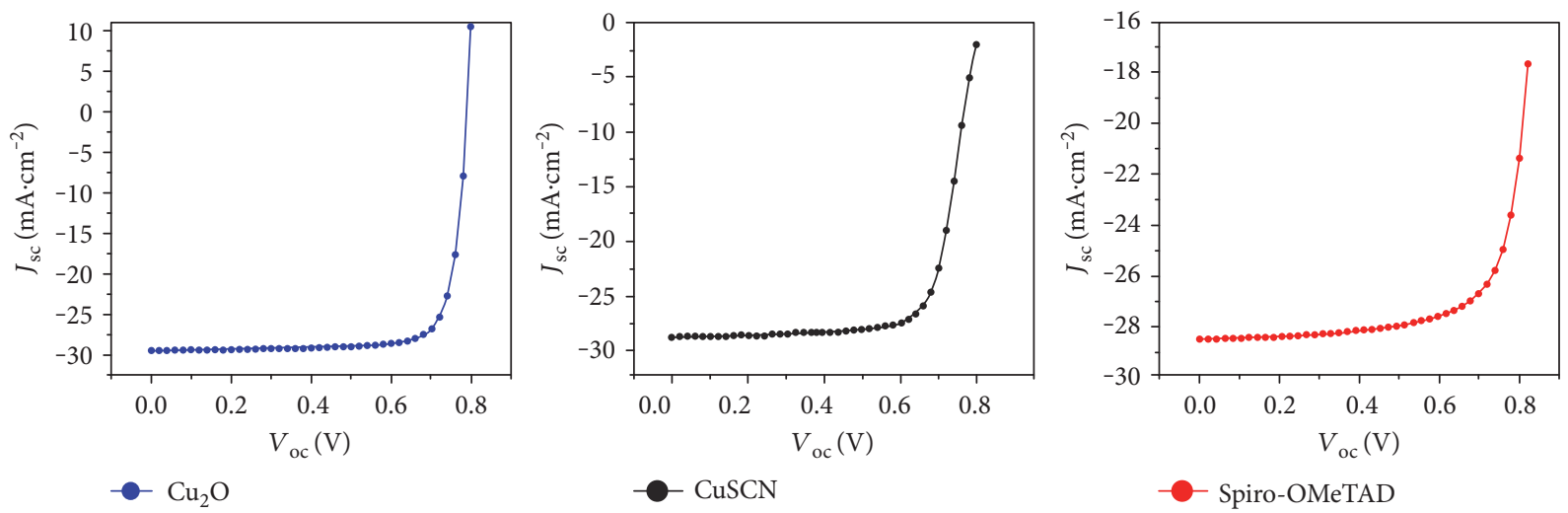

Figure 9: $J-V$ curves for different HTM-based PSCs.

TABle 5: Performance of Pb-free $\mathrm{ZnO}$ nanorod-based PSCs with different HTM layers.

\begin{tabular}{lcccc}
\hline Perovskite solar cell & $J_{\mathrm{sc}}\left(\mathrm{mA} \cdot \mathrm{cm}^{-2}\right)$ & $V_{\mathrm{oc}}(\mathrm{V})$ & FF $(\%)$ & PCE $(\%)$ \\
\hline $\mathrm{ZnO}(\mathrm{nr}) / \mathrm{CH}_{3} \mathrm{NH}_{3} \mathrm{SnI}_{3} /$ spiro-OMeTAD & 31.84 & 0.9024 & 72.71 & 20.21 \\
$\mathrm{ZnO}(\mathrm{nr}) / \mathrm{CH}_{3} \mathrm{NH}_{3} \mathrm{SnI}_{3} / \mathrm{CuSCN}$ & 31.91 & 0.8289 & 70.31 & 18.34 \\
$\mathrm{ZnO}(\mathrm{nr}) / \mathrm{CH}_{3} \mathrm{NH}_{3} \mathrm{SnI}_{3} / \mathrm{Cu}_{2} \mathrm{O}$ & 32.26 & 0.8467 & 74.02 & 20.23 \\
\hline
\end{tabular}

characteristics, effect of some fundamental material parameters such as bandgap, electron affinity, dielectric permittivity, electron, and hole mobility has also been observed using different HTM layers. The optimum values of parameters are based on reported literatures $[2,8,9]$ which are summarized in Table 1. Figure 9 shows the $I-V$ curves for PSCs having $\mathrm{Cu}_{2} \mathrm{O}, \mathrm{CuSCN}$, and spiro-OMeTAD as the HTM layer. The thickness of the perovskite layer has been varied from 350 to $1000 \mathrm{~nm}$.

$I-V$ characteristics of all three $\mathrm{Pb}$-free $\mathrm{ZnO}$ nanorodbased PSC structures are shown in Table 4 considering the perovskite layer with thickness of $450 \mathrm{~nm}$, valance band density of states of $1 \times 10^{18} \mathrm{~cm}^{-3}$, interface defect density of $1 \times 10^{12} \mathrm{~cm}^{-3}$, and Au back for performing numerical analysis.

From Table 5, it can be perceived that $\mathrm{ZnO} \mathrm{nr} /$ $\mathrm{CH}_{3} \mathrm{NH}_{3} \mathrm{SnI}_{3} / \mathrm{Cu}_{2} \mathrm{O}$ structure has given the best performance among all the PSCs. This suggests $\mathrm{Cu}_{2} \mathrm{O}$ as a suitable HTM layer for $\mathrm{Pb}$-free solar cell fabrication.

\section{Comparison between Typical PSC and Pb-Free ZnO Nanorod-Based PSC}

To evaluate the effectiveness and usability of our proposed lead-free $\mathrm{ZnO}$ nanorod-based PSC structure, we have compared it with Glass/FTO/ZnO nr/CH $\mathrm{CH}_{3} \mathrm{PbI}_{3} / \mathrm{HTM} /$ $\mathrm{Au}$ structure by performing simulation with SCAPS-1D simulator. Methylammonium tin triiodide perovskites are thought to be a potential substitute to conventional methylammonium lead triiodide perovskites because it has a direct bandgap of $1.3 \mathrm{eV}$ [15]. Besides, it is earth abundant and free of toxicity. For both of the structures, we have considered $\mathrm{Cu}_{2} \mathrm{O}$ as the HTM layer since from the previous simulations, it has been concluded that $\mathrm{Cu}_{2} \mathrm{O}$ ensures the highest performance. Cuprous oxide $\left(\mathrm{Cu}_{2} \mathrm{O}\right)$ is a p-type semiconductor with a direct bandgap of $2.17 \mathrm{eV}$ [19]. Its low electron affinity safeguards high-hole mobility which makes it suitable as a hole transport material (HTM) in heterojunction solar cells. Thus, it is considered to be a potential HTM layer for PSCs which has not been practically implemented yet. However, this layer can be deposited by several techniques such as sputtering, copper oxidation, spin coating, and atomic layer deposition (ALD).

For modeling and simulation of methylammonium lead triiodide PSC, we have followed the structure proposed by Lee et al. [20] where the methylammonium lead triiodide was produced from methylammonium lead iodide chloride $\left(\mathrm{CH}_{3} \mathrm{NH}_{3} \mathrm{PbI}_{2} \mathrm{Cl}\right)$ by spin coating using $\mathrm{N}$, $\mathrm{N}$-dimethylformamide as precursor solution. We have considered $\mathrm{Cu}_{2} \mathrm{O}$ as the HTM layer and $\mathrm{Au}$ as back contact. For the simulations of lead-free $\mathrm{ZnO}$ nanorod-based PSC structure, we have considered the experimental work conducted by Dong et al. [3]. Here, the Al-doped $\mathrm{ZnO}$ nanorods were produced above the $\mathrm{ZnO}$ seed layer by sol-gel method and $\mathrm{CH}_{3} \mathrm{NH}_{3} \mathrm{PbI}_{3}$ was deposited onto $\mathrm{ZnO}$ film [3, 4]. Unlike the structure suggested by Dong et al., we have used $\mathrm{CH}_{3} \mathrm{NH}_{3} \mathrm{SnI}_{3}$ as a layer instead of $\mathrm{CH}_{3} \mathrm{NH}_{3} \mathrm{PbI}_{3}$. For the ETM layer, we have considered Al-doped $\mathrm{ZnO}$ nanorod by setting higher electron density, higher electron mobility, and higher conduction band than pure $\mathrm{ZnO}$.

Values of parameters used for the simulation of both the structures are based on experimental study, literature values, or in some cases reasonable estimation in accord with the simulation procedure $[8,11,21-24]$.

Figure 10 shows the device structure of methylammonium lead triiodide PSC structure suggested by Lee et al. [20] along with our proposed $\mathrm{Pb}$-free $\mathrm{ZnO}$ nanorod-based PSC.

From Table 6, we can see that the overall performance of both structures is somewhat similar. The efficiency and fill factor has shown some improvement for the $\mathrm{Pb}$-free $\mathrm{ZnO}$ 

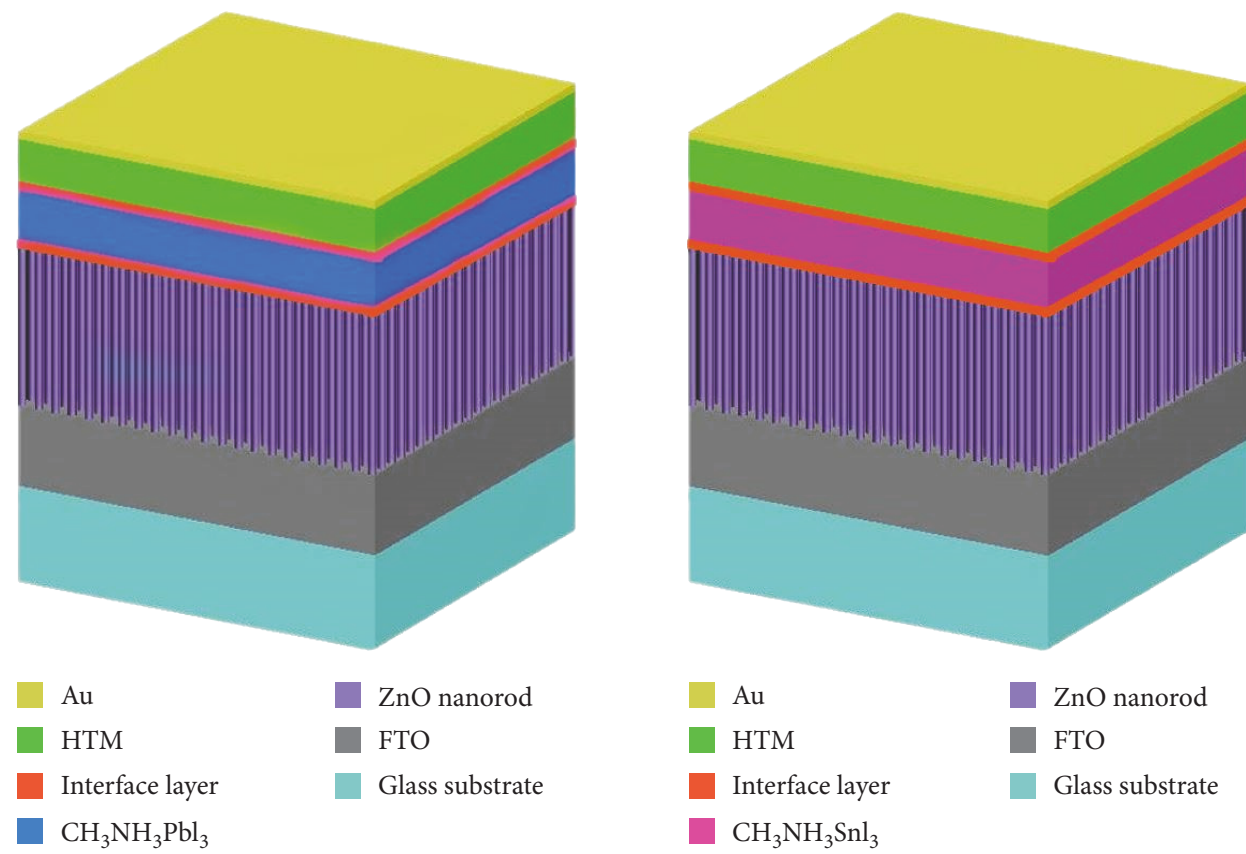

Figure 10: Device structure of methylammonium lead triiodide $\mathrm{ZnO}$ nanorod-based PSC and Pb-free $\mathrm{ZnO}$ nanorod-based PSC.

TABLE 6: $I-V$ characteristics of methylammonium lead triiodide PSC and $\mathrm{Pb}$-free $\mathrm{ZnO}$ nanorod-based PSC.

\begin{tabular}{lcc}
\hline Solar cell parameters & $\begin{array}{c}\text { ZnO nr-based } \\
\text { methylammonium } \\
\text { lead triiodide PSC }\end{array}$ & $\begin{array}{c}\text { ZnO nr-based } \\
\text { methylammonium } \\
\text { tin triiodide PSC }\end{array}$ \\
\hline $\begin{array}{l}\text { Open circuit voltage, } \\
V_{\text {oc }}(\mathrm{V})\end{array}$ & 0.98 & 0.85 \\
$\begin{array}{l}\text { Short circuit current, } \\
J_{\text {sc }}\left(\mathrm{mA} / \mathrm{cm}^{2}\right)\end{array}$ & 25.05 & 32.26 \\
Fill factor, FF (\%) & 73.81 & 74.02 \\
Efficiency $(\%)$ & 18.31 & 20.23 \\
\hline
\end{tabular}

nanorod-based PSC. For methylammonium lead triiodide PSC and methylammonium tin triiodide PSC structures, the efficiency is $18.31 \%$ and $20.23 \%$ while the $\mathrm{FF}$ is $73.81 \%$ and $74.02 \%$, respectively. The open circuit voltage and short circuit current have not shown any significant change. Thus, the result justifies the possibility of our proposed $\mathrm{Pb}$-free $\mathrm{ZnO}$ nanorod-based PSC model to be considered as a potential alternative to conventional perovskite solar cell.

\section{Conclusion}

For the simulations of $\mathrm{Pb}$-free $\mathrm{ZnO}$ nanorod-based $\mathrm{PSC}$ model, spiro-OMeTAD, $\mathrm{Cu}_{2} \mathrm{O}$, and $\mathrm{CuSCN}$ have been used as the HTM layer. From the simulations, it has been deduced that $I-V$ characteristics of all the $\mathrm{Pb}$-free $\mathrm{ZnO}$ nanorod-based PSC models have indicated high-efficiency performance. Among them, the best performance has been achieved for $\mathrm{ZnO} \mathrm{nr} / \mathrm{CH}_{3} \mathrm{NH}_{3} \mathrm{SnI}_{3} / \mathrm{Cu}_{2} \mathrm{O}$ PSC structure $\left(J_{\mathrm{sc}}=32.26 \mathrm{~mA}\right.$, $V_{\mathrm{oc}}=0.85 \mathrm{~V}, \mathrm{FF}=74.02 \%$, and $\mathrm{PCE}=20.23 \%$ ). For the justification of our proposed model, simulation has been done for $\mathrm{ZnO}$ nanorod-based methylammonium lead triiodide PSC structure. By comparing the two structures, it can be concluded that performance of both structures was almost similar and $\mathrm{Pb}$-free $\mathrm{ZnO}$ nanorod gave approximately $2 \%$ higher efficiency. Simulations have been done to analyze the effects of electrical parameters on $\mathrm{Pb}$-free $\mathrm{ZnO}$ nanorodbased PSCs. A downfall of efficiency has been noticed with the increase of trap density at the interface layers. Different back contacts were used for simulations to evaluate their effect on the performance of our proposed models. From the results of the simulations, it can be summarized that $\mathrm{ZnO} \mathrm{nr} / \mathrm{CH}_{3} \mathrm{NH}_{3} \mathrm{SnI}_{3} / \mathrm{Cu}_{2} \mathrm{O}$ PSC structure is a potential alternative for the third generation solar cell which can be reasonably efficient and inexpensive. For further improvement of performance, other perovskite materials such as $\mathrm{CH}_{3} \mathrm{NH}_{3} \mathrm{SnI}_{3-x} \mathrm{Br}_{x}(x=0,1,2$, and 3$)$ can be used as an absorber layer [24]. Experimental studies are needed for extensive investigation regarding our proposed PSC structure.

\section{Conflicts of Interest}

No potential conflict of interest was reported by the authors.

\section{Acknowledgments}

The authors' heartiest acknowledgment goes to Dr. Marc Burgelman at the University of Gent for providing SCAPS-1D.

\section{References}

[1] H.-J. Du, W.-C. Wang, and J.-Z. Zhu, "Device simulation of lead-free $\mathrm{CH}_{3} \mathrm{NH}_{3} \mathrm{SnI}_{3}$ perovskite solar cells with high efficiency," Chinese Physics B, vol. 25, article 108802, 2016.

[2] P. Umari, E. Mosconi, and F. De Angelis, "Relativistic GW calculations on $\mathrm{CH}_{3} \mathrm{NH}_{3} \mathrm{PbI}_{3}$ and $\mathrm{CH}_{3} \mathrm{NH}_{3} \mathrm{SnI}_{3}$ perovskites 
for solar cell applications," Scientific Reports, vol. 4, p. 4467, 2014.

[3] J. Dong, Y. Zhao, J. Shi et al., "Impressive enhancement in the cell performance of $\mathrm{ZnO}$ nanorod-based perovskite solar cells with Al-doped $\mathrm{ZnO}$ interfacial modification," Chemical Communications, vol. 50, no. 87, pp. 13381-13384, 2014.

[4] D.-Y. Son, J.-H. Im, H.-S. Kim, and N.-G. Park, "11\% efficient perovskite solar cell based on $\mathrm{ZnO}$ nanorods: an effective charge collection system," The Journal of Physical Chemistry C, vol. 118, no. 30, pp. 16567-16573, 2014.

[5] X. Yang, T. Liu, Z. Li et al., "Preparation and photovoltaic properties of perovskite solar cell based on $\mathrm{ZnO}$ nanorod arrays," Applied Surface Science, vol. 388, Part A, pp. 89-96, 2016.

[6] D. B. Mitzi, C. Feild, Z. Schlesinger, and R. Laibowitz, "Transport, optical, and magnetic properties of the conducting halide perovskite $\mathrm{CH}_{3} \mathrm{NH}_{3} \mathrm{SnI}_{3}$," Journal of Solid State Chemistry, vol. 114, pp. 159-163, 1995.

[7] A. Niemegeers, M. Burgelman, and K. Decock, SCAPS manual, 2013.

[8] M. I. Hossain, F. H. Alharbi, and N. Tabet, "Copper oxide as inorganic hole transport material for lead halide perovskite based solar cells," Solar Energy, vol. 120, pp. 370-380, 2015.

[9] R. Mahbub, M. S. Islam, F. Anwar, S. S. Satter, and S. M. Ullah, "Simulation of CZTS thin film solar cell for different buffer layers for high efficiency performance," South Asian Journal of Engineering and Technology, vol. 2, p. 1, 2016.

[10] Y.-J. Lee, D. S. Ruby, D. W. Peters, B. B. McKenzie, and J. W. P. $\mathrm{Hsu}$, " $\mathrm{ZnO}$ nanostructures as efficient antireflection layers in solar cells," Nano Letters, vol. 8, no. 5, pp. 1501-1505, 2008.

[11] M. Hossain, O. Daif, N. Amin, F. Alharbi, and N. Tabet, TMS Middle East - Mediterranean Materials Congress on Energy and Infrastructure Systems (MEMA 2015), 2013.

[12] S. Bansal and P. Aryal, "Evaluation of new materials for electron and hole transport layers in perovskite-based solar cells through SCAPS-1D simulations," in 2016 IEEE 43rd Photovoltaic Specialists Conference (PVSC), Portland, OR, USA, June 2016.

[13] J.-P. Correa-Baena, M. Anaya, G. Lozano et al., "Unbroken perovskite: interplay of morphology, electro-optical properties, and ionic movement," Advanced Materials, vol. 28, no. 5031, p. 7, 2016.

[14] K. Tan, P. Lin, G. Wang, Y. Liu, Z. Xu, and Y. Lin, “Controllable design of solid-state perovskite solar cells by SCAPS device simulation," Solid-State Electronic, vol. 126, pp. 75-80, 2016.

[15] A. Iefanova, N. Adhikari, A. Dubey, D. Khatiwada, and Q. Qiaoa, "Lead free $\mathrm{CH}_{3} \mathrm{NH}_{3} \mathrm{SnI}_{3}$ perovskite thin-film with p-type semiconducting nature and metal-like conductivity," AIP Advances, vol. 6, article 085312, 2016.

[16] P. Liu, V. P. Singh, C. A. Jarro, and S. Rajaputra, "Cadmium sulfide nanowires for the window semiconductor layer in thin film CdS-CdTe solar cells," Nanotechnology, vol. 22, no. 14, 2011.

[17] F. Behrouznejad, S. Shahbazi, N. Taghavinia, H.-P. Wu, and E. W.-G. Diau, "A study on utilizing different metals as the back contact of $\mathrm{CH}_{3} \mathrm{NH}_{3} \mathrm{PbI}_{3}$ perovskite solar cells," Journal of Materials Chemistry A, vol. 4, pp. 13488-13498, 2016.

[18] P. Qin, S. Tanaka, S. Ito et al., "Inorganic hole conductor-based lead halide perovskite solar cells with $12.4 \%$ conversion efficiency," Nature Communications, vol. 5, no. 3834, 2014.
[19] J. Robertson and B. Falabretti, Springer: Handbook of Transparent Conductor, Chapter 2, 2011.

[20] M. M. Lee, J. Teuscher, T. Miyasaka, T. N. Murakami, and H. J. Snaith, "Efficient hybrid solar cells based on mesosuperstructured organometal halide perovskites," Science, vol. 338, no. 6107, pp. 643-647, 2012.

[21] F. Liu, J. Zhu, J. Wei et al., "Numerical simulation: toward the design of high-efficiency planar perovskite solar cells," Applied Physics Letters, vol. 104, article 253508, 2014.

[22] T. Minemoto and M. Murata, "Impact of work function of back contact of perovskite solar cells without hole transport material analyzed by device simulation," Current Applied Physics, vol. 14, pp. 1428-1433, 2014.

[23] B. M. Soucase, I. G. Pradas, and K. R. Adhikari, InTech: Perovskite Materials - Synthesis, Characterisation, Properties, and Applications, Chapter 15, 2016.

[24] L. Huang, X. Sun, C. Li et al., "Electron transport layer-free planar perovskite solar cells: further performance enhancement perspective from device simulation," Solar Energy Materials and Solar Cells, vol. 157, pp. 1038-1047, 2016. 

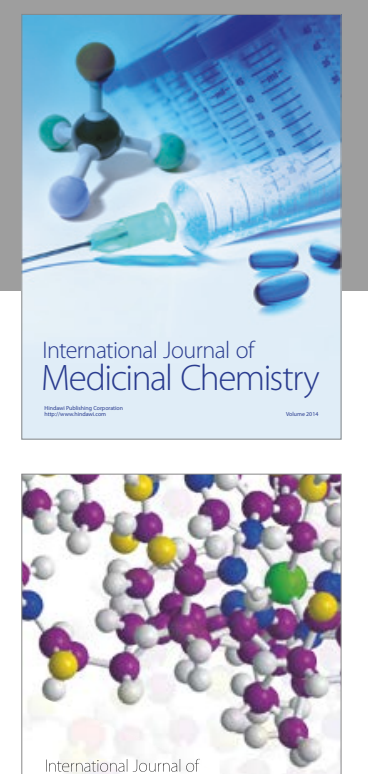

Carbohydrate Chemistry

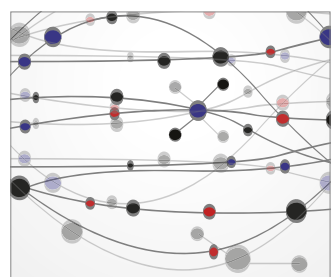

The Scientific World Journal
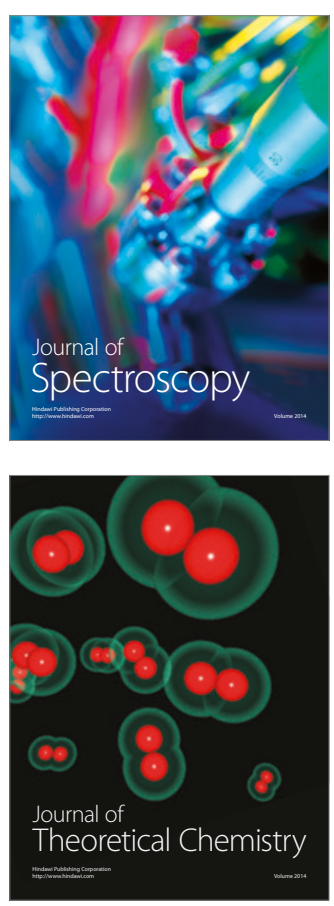
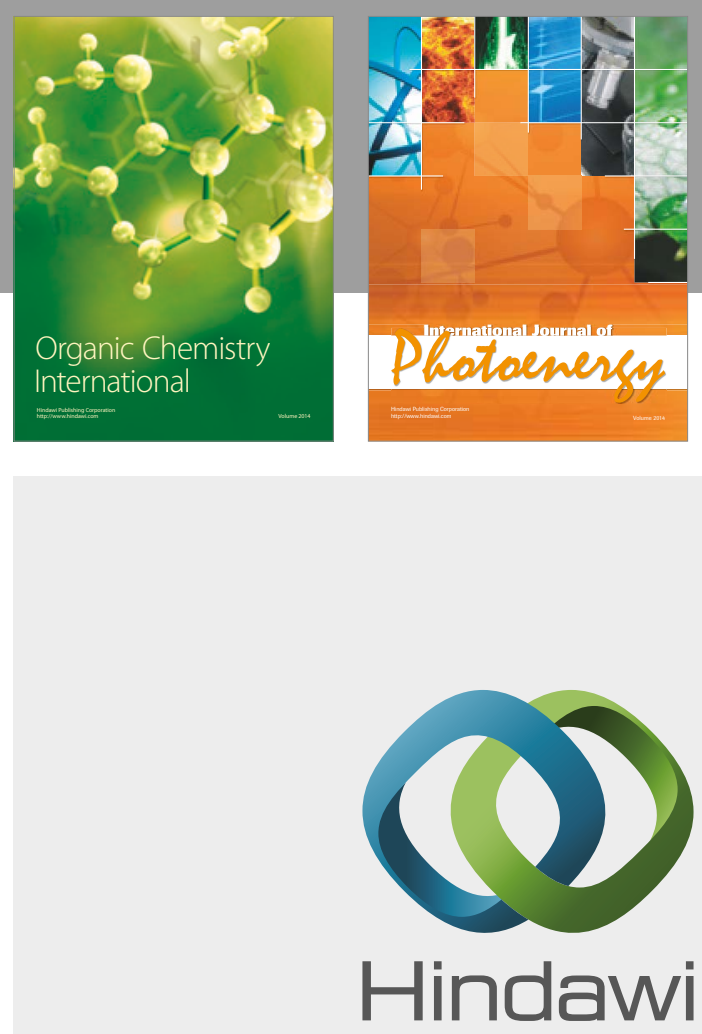

Submit your manuscripts at

https://www.hindawi.com

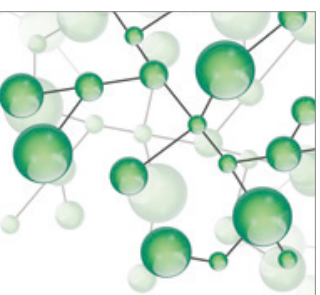

International Journal of

Inorganic Chemistry

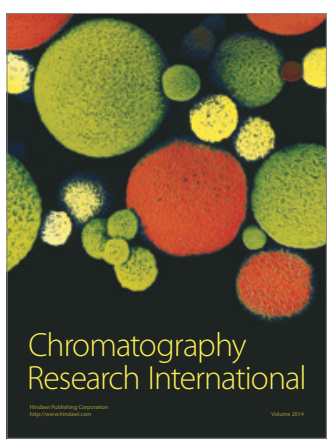

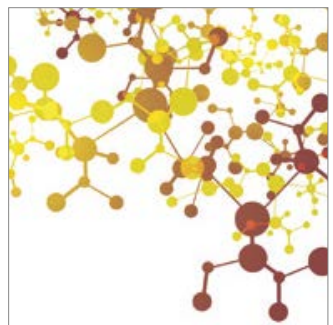

Applied Chemistry
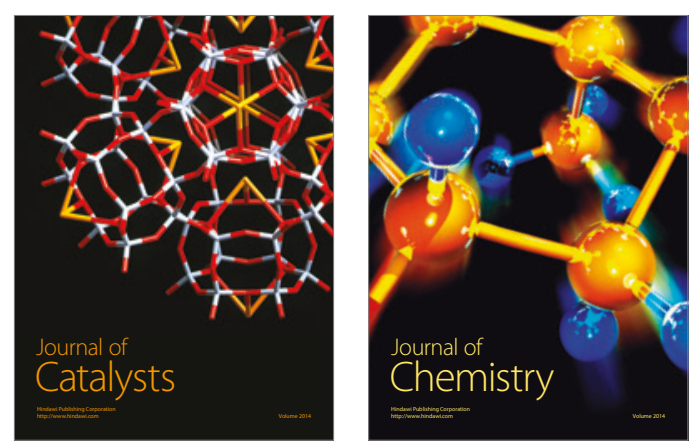
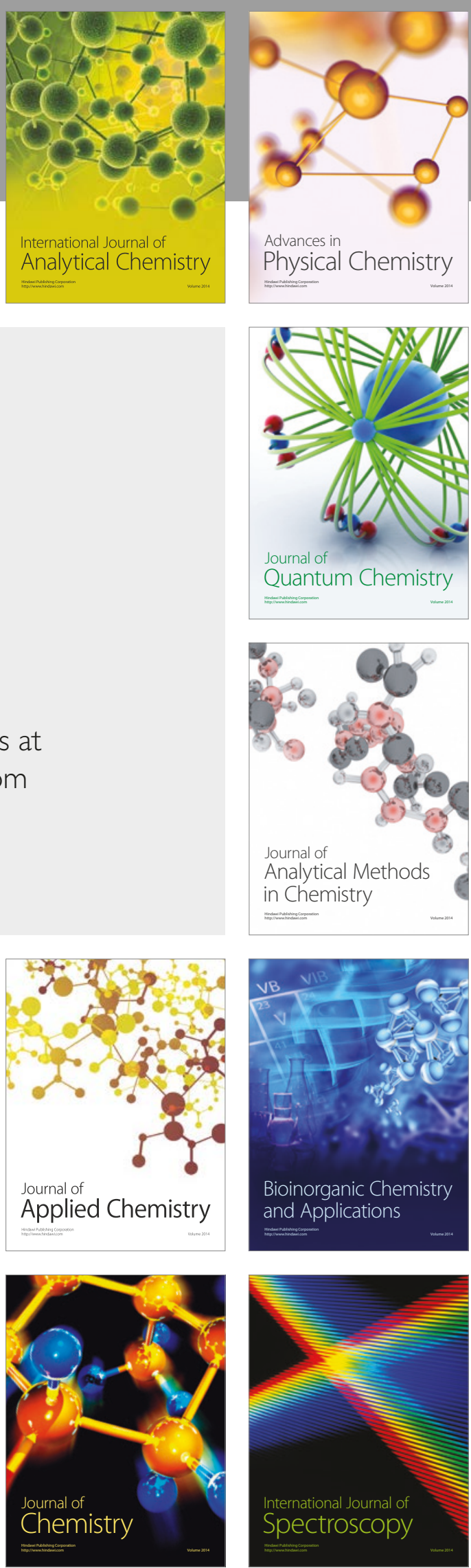